\title{
PENINGKATAN MOTIVASI DAN PRESTASI BELAJAR BIOLOGI KELAS X-7 SMA N 1 BARAT MELALUI PENERAPAN MODEL THINK PAIR SHARE
}

\author{
Nunuk Purwanti \\ SMA Negeri 1 Barat Kabupaten Magetan \\ Email: yuhan_bee_club@yahoo.com \\ Diterima 5 Juli, Disetujui 17 Oktober 2015
}

\begin{abstract}
Motivation plays an important role in learning, X-7 grade students of SMA Negeri 1 Barat shows the known to be less motivated to follow the teaching of Biology. The aim of research to increase the motivation to learn biology X - 7 grade SMA Negeri 1 Barat with the application Think Pair Share (TPS). This type of research is classroom action research with planning, action, observation, and reflection, material monera and protists conducted in two cycles. Research subject class X-7 SMA Negeri 1 Barat of academic year 2014/2015. The results showed cooperative learning Think Pair Share can help students overcome the problem for expression and enhance self-confidence of students, so as to increase the motivation of students.
\end{abstract}

Keywords: motivation to learn, think pair share

\section{PENDAHULUAN}

Kurikulum Tingkat Satuan Pendidikan (KTSP) guru diharapkan tidak hanya memberikan pengetahuan kepada siswa tetapi membantu siswa untuk membangun pengetahuannya. Salah satu cara untuk mencapai proses pembelajaran yang efektif dan dapat meningkatkan hasil belajar siswa adalah menggunakan suatu metode pembelajaran yang relevan. Pelaksanaan metode pembelajaran disesuaikan dengan kondisi yang terjadi pada saat pelajaran berlangsung.

Siswa dapat membangun sendiri pengetahuan jika siswa mempunyai ketertarikan terhadap suatu pembelajaran. Ketertarikan siswa akan menumbuhkan rasa ingin tahu, siswa akan berusaha mencari berbagai sumber belajar dan aktif di dalam kelas, untuk itu diperlukan motivasi belajar pada diri siswa. Motivasi belajar merupakan dorongan yang timbul pada diri siswa secara sadar atau tidak sadar untuk belajar dengan tujuan tertentu. Indikator motivasi dapat dilihat melalui attention, relevance, confident, dan satisfaction siswa terhadap pembelajaran. Motivasi belajar siswa akan terpelihara apabila mereka menganggap bahwa apa yang dipelajari memenuhi kebutuhan pribadi atau bermanfaat dan sesuai dengan nilai yang dipegang (Qadriyah, 2002).

Deskriptor attention dapat berupa menunjukkan rasa senang terhadap pelajaran, menunjukkan rasa ingin tahu, bertanggung jawab terhadap tugas, dan keaktifan dalam kegiatan pembelajaran. Attention atau perhatian siswa muncul karena didorong rasa ingin tahu. Oleh sebab itu rasa ingin tahu perlu mendapat rangsangan sehingga siswa akan memberikan perhatian, dan perhatian tersebut terpelihara selama berlangsungnya pembelajaran, bahkan lebih lama lagi (Keller, 1987). Deskriptor relevance berupa memahami apa yang dipelajari dalam pembelajaran. Deskriptor confident berupa percaya diri menyampaikan pendapat, percaya diri mengajukan pertanyaan, dan percaya diri menjawab pertanyaan sedangkan deskriptor satisfaction berupa puas atas jawaban yang diberikan oleh teman atau guru dan kehadiran di kelas. Motivasi sangat penting dalam proses 
pembelajaran siswa. Motivasi merupakan faktor yang sangat penting untuk menentukan keberhasilan dalam belajar. Seseorang yang memiliki motivasi tinggi belajar sangat giat, melakukan sesuatu dengan baik, lebih baik dari pada yang pernah dilakukan sebelumnya, serta belajar lebih efisien dan lebih cepat (Qadriyah, 2002).

Berdasarkan pengamatan pada semester ganjil tahun 2014/2015 di SMAN 1 Barat, diketahui bahwa siswa kelas X-7 kurang memperlihatkan motivasi mengikuti pembelajaran Biologi, siswa hanya mendengarkan penjelasan guru tanpa ada motivasi untuk mencari lebih banyak pengetahuan lain yang berhubungan dengan materi. Bardasarkan hasil analisis data menunjukkan bahwa hanya $10 \%$ yang memiliki motivasi tinggi terhadap pembelajaran Biologi, terbukti pada saat kegiatan diskusi siswa hanya bertanya ketika guru meminta siswa untuk bertanya. Kegiatan diskusi kelompok tidak semua siswa ikut serta dalam mengerjakan tugas kelompok, banyak siswa masih mengerjakan kegiatan sendiri dan tidak memperhatikan guru. Kegiatan diskusi kelas atau presentasi tidak semua siswa aktif bertanya. Hasil pengamatan menunjukkan siswa dengan kemampuan akademik tinggi tetapi tidak memiliki motivasi belajar baik.

Salah satu usaha yang dapat meningkatkan motivasi belajar Biologi adalah dengan menggunakan Think Pair Share (TPS) merupakan suatu strategi diskusi kooperatif yang dikembangkan oleh Frank Lyman memperkenalkan ide adanya waktu berpikir atau waktu tunggu yang banyak menjadi faktor kuat dalam meningkatkan kemampuan siswa merespon pertanyaan. Penggunaan model TPS dipilih berdasarkan pendapat Prayitno (1989) menyatakan bahwa model TPS membawa siswa pada sebuah kecerdasan hidup. Siswa menjadi cerdas dalam proses berpikir dan menyampaikan buah pikiran. Model TPS juga dapat mengarahkan siswa untuk menerima pengetahuan tidak hanya dari satu sumber tetapi dari berbagai sumber sehingga meningkatkan kemampuan kognitif (Ewbank Eur, 1947 dalam Wulandari, 2008). Model TPS dalam penelitian ini merupakan suatu cara penyajian pelajaran yang melibatkan siswa secara individu maupun kelompok menyelesaikan permasalahan nyata yang ada di sekitar siswa. Terdapat empat langkah atau tahapan dalam pembelajaran TPS, sebagai berikut.

Tahap 1 siswa berpikir secara individu, guru memberi tanda agar siswa mulai memikirkan pertanyaan atau masalah yang diberikan guru dalam waktu tertentu. Lamanya waktu ditetapkan oleh guru berdasarkan pemahaman guru terhadap siswanya, sifat pertanyaannya dan skenario pembelajaran. Tahap 2 setiap siswa mendiskusikan jawabannya dengan seorang mitra, guru memberi tanda agar siswa mulai berpasangan dengan siswa lainnya untuk mendiskusikan dan mencapai kesepakatan atas jawaban terhadap pertanyaa. Siswa membandingkan hasil pemikiran ataupun jawaban yang paling baik, meyakinkan, atau unik. Tahap 2 dapat diperpanjang satu langkah lebih lanjut yaitu dengan meminta pasangan siswa bergabung dengan pasangan lainnya sehingga membentuk kelompok baru yang terdiri dari empat orang, selanjutnya anggota kelompok menggabungkan ide sebelum membandingkannya ke kelompok lain yang lebih besar.

Tahap 3 siswa berbagi jawaban dengan seluruh kelas, untuk melaporkan hasil diskusinya ke seluruh kelas. Tahap terakhir TPS, siswa seluruh kelas akan memperoleh keuntungan dalam bentuk mendengarkan berbagai ungkapan mengenai konsep yang sama dinyatakan dengan cara yang berbeda oleh individu yang berbeda, hal ini terjadi karena siswa memiliki cara penyampaian jawaban yang unik untuk pertanyaan yang diajukan oleh guru.Tujuan penelitian untuk meningkatkan prestasi dan motivasi belajar Biologi kelas X-7 SMA Negeri 1 Barat melalui Penerapan model Think Pair Share (TPS). 


\section{METODE}

\section{Rancangan Penelitian}

Subjek penelitian adalah seluruh siswa kelas X-7 SMAN 1 Barat semester ganjil tahun ajaran 2014/015. Jumlah siswa 34 terdiri dari 10 siswa laki-laki dan 24 siswa perempuan. Rancangan penelitian menggunakan penelitian tindakan kelas (PTK), dilaksanakan sebanyak dua siklus. Setiap siklus melalui tahapan: a) perencanaan, b) pelaksanaan, c) pengamatan, dan d) refleksi. Adapun kegiatan penelitian tiap siklus yang dilaksanakan dalam setiap tahapan adalah sebagai berikut.

\section{Tahap perencanaan}

Menyusun perangkat pembelajaran berupa silabus, RPP, menyiapkan media berupa power point, menyusun lembar kerja siswa, menyusun instrumen penelitian yang berupa pedoman pengamatan, catatan lapangan, lembar observasi motivasi belajar siswa, tes hasil belajar dan lembar pengamatan kinerja laboratorium.

\section{Tahap pengamatan}

Pengamatan dilaksanakan selama pembelajaran berlangsung menggunakan instrumen pengamatan berupa catatan lapangan, lembar observasi keterlaksanaan guru, lembar observasi keterlaksanaan siswa, lembar observasi motivasi belajar siswa dan lembar observasi praktikum.

\section{Tahap refleksi.}

Hasil refleksi digunakan sebagai evaluasi untuk keberhasilan tindakan pada siklus II. Indikator keberhasilan penelitian digunakan pedoman sebagai berikut. 1) Motivasi belajar siswa: keberhasilan motivasi belajar siswa dilihat nilai masingmasing indikator motivasi belajar siswa yang diukur dengan pedoman penentuan taraf keberhasilan motivasi belajar siswa. Indikator motivasi belajar siswa yang meliputi attention, relevance, confident, dan satisfaction. 2) Hasil belajar: hasil belajar kognitif dikatakan tuntas secara klasikal jika minimal 85\% siswa tuntas. Adapun kriteria ketuntasan kognitif individu adalah perolehan nilai 75 , hasil ketuntasan belajar afektif minimal $85 \%$, hasil ketuntasan belajar psikomotor minimal $85 \%$.

\section{Teknik Analisis Data}

Data dianalisis secara kualitatif, yang meliputi beberapa tahap: a) reduksi data, merupakan proses pemilihan, pemusatan perhatian pada penyederhanaan (membuang yang tidak perlu), pengabstrakan dan transformasi data yang muncul dari lembar observasi dan catatan lapangan sehingga dapat ditarik kesimpulan dan diverifikasi; b) penyajian data, merupakan pengorganisasian data hasil reduksi dalam bentuk naratif yang memungkinkan untuk penarikan kesimpulan dan pengambilan tindakan, selanjutnya sajian tersebut ditafsirkan dan dievaluasi untuk merencanakan tindakan berikutnya, dan c) penarikan kesimpulan, merupakan kegiatan yang dimaksudkan untuk memberikan kesimpulan terhadap hasil penafsiran dan evaluasi.

Data motivasi belajar dianalisis secara diskriptif dengan menghitung persentase belajar klasikal sesuai indikator yang sudah ditetapkan dengan rumus sebagai berikut.

$$
\begin{aligned}
\text { MBKi }=\frac{\sum S d i}{\operatorname{Smax} X n} \times 100 \% \\
\mathrm{MBKi}=\begin{array}{l}
\text { Motivasi belajar klasikal setiap } \\
\text { indikator }
\end{array} \\
\sum \mathrm{Sdi}=\begin{array}{l}
\text { Jumlah skor deskriptor yang muncul di } \\
\text { setiap indikator }
\end{array} \\
\mathrm{Smax}=\begin{array}{l}
\text { Skor maksimal indikator (jumlah } \\
\text { deskriptor X skor maksimal deskriptor) }
\end{array}
\end{aligned}
$$

Motivasi belajar klasikal keseluruhan adalah persentase nilai motivasi yang diperoleh seluruh siswa untuk semua indikator motivasi, dengan menggunakan rumus sebagai berikut.

$$
\begin{aligned}
& \text { MBKk }=\frac{\sum\left(\sum S d i\right)}{\sum S \max \times n} \times 100 \% \\
& \text { MBKk = Motivasi belajar klasikal } \\
& \text { keseluruhan } \\
& \sum\left(\sum \text { Sdi }\right)=\text { Total jumlah skor deskriptor } \\
& \text { yang muncul di setiap } \\
& \text { indikator } \\
& \sum \text { Smax }=\text { Total skor maksimal indikator }
\end{aligned}
$$


Berdasarkan nilai motivasi klasikal setiap indikator maupun keseluruhan indikator dapat ditentukan kategori taraf keberhasilan motivasi belajar siswa. Penentuan taraf keberhasilan motivasi belajar siswa berpedoman pada Tabel 1 .

Tabel 1. Pedoman Penentuan Kategori Taraf Keberhasilan Motivasi Belajar Siswa

\begin{tabular}{|c|c|c|c|c|}
\hline No. & Skor & Grade & Skala & Keterangan \\
\hline 1 & $91-100$ & A & 4,0 & Istimewa \\
\hline 2 & $81-90$ & $B+$ & 3,5 & Sangat Baik \\
\hline 3 & $75-80$ & B & 3 & Baik \\
\hline 4 & $64-74$ & $\mathrm{C}+$ & 2,5 & Cukup \\
\hline 5 & $55-64$ & $\mathrm{C}$ & 2,0 & Kurang \\
\hline 6 & $50-54$ & D+ & 1,5 & $\begin{array}{l}\text { Sangat } \\
\text { Kurang }\end{array}$ \\
\hline 7 & $30-49$ & D & 1.0 & $\begin{array}{l}\text { Sangat } \\
\text { Kurang }\end{array}$ \\
\hline 8 & $0-29$ & $\mathrm{E}$ & 0 & $\begin{array}{l}\text { Sekali } \\
\text { Gagal }\end{array}$ \\
\hline
\end{tabular}

\section{HASIL DAN PEMBAHASAN}

Guru membuka pelajaran, siswa menyiapkan diri untuk belajar, siswa mengumpulkan tugas analisis kritis artikel yang telah ditugaskan pada pertemuan sebelumnya. Guru memotivasi siswa, dengan mereview materi pada pertemuan sebelumnya dan dengan menggali pengetahuan awal siswa tentang cara hidup virus dan cara virus melakukan replikasi pada sel/jaringan hidup. Siswa menjawab pertanyaan-pertanyaan guru yang mengarahkan siswa pada materi yang akan dipelajari. Berdasarkan hasil observasi yang dilaksanakan ada perbedaan antara siklus I dan siklus II adalah: hasil observasi siklus I terdapat beberapa temuan, yaitu siswa masih kurang percaya diri dalam menyampaikan pendapat, siswa masih ragu-ragu dan belum paham prosedur melaksanakan praktikum, hasil motivasi klasikal keseluruhan siklus I sebesar 68,333\%, ketuntasan klasikal keseluruhan siklus I sebesar $85,71 \%$ dengan rata-rata kognitif sebesar 81 , afektif 81 dan psikomotor 82.

Hasil observasi siklus II terdapat beberapa temuan, yaitu siswa lebih percaya diri dalam mengemukakan pertanyaan maupun pendapat, pelaksanaan praktikum sudah paham dan mengerti apa yang harus dilakukan, hasil motivasi klasikal keseluruhan siklus II 92,083\%, ketuntasan klasikal keseluruhan siklus II 91,18\% ratarata nilai kognitif 82 , nilai afektif 83 dan nilai psikomotor 86 . Berdasarkan paparan tersebut, terdapat peningkatan motivasi dan hasil belajar pada siklus II. Peningkatan motivasi belajar meningkat sebesar 23,75\% pada siklus II dan ketuntasan klasikal keseluruhan siklus II meningkat sebesar 6\% (Gambar 1).

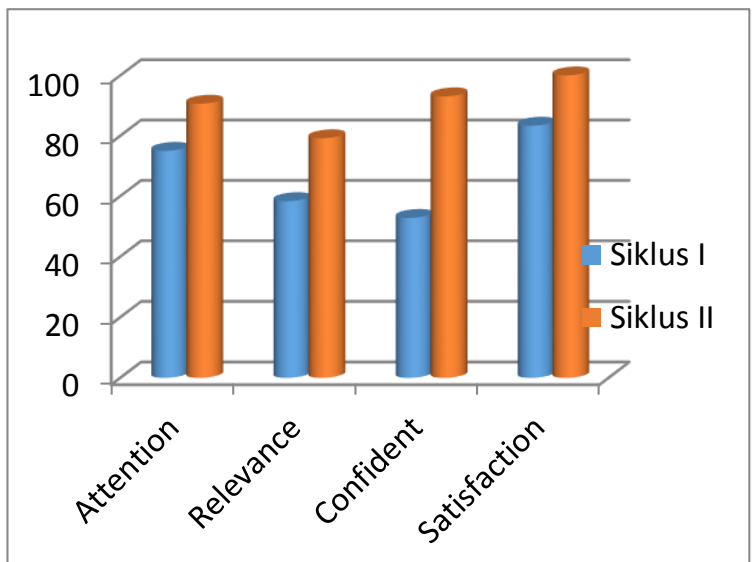

Gambar 1. Peningkatan motivasi belajar siklus II dan siklus II

Hasil refleksi siklus I dinyatakan bahwa: a) siswa masih ragu untuk mengemukakan ide, pendapat tentang materi archaebacteria, b) pada saat diskusi jawaban siswa masih didominasi siswa tertentu saja, c) kepercayaan diri siswa masih kurang, sehingga terlihat motivasi belajar masih kurang, d) inisiatif siswa masih kurang, dalam praktikum guru masih dominan memberi komando dari menyediakan alat bahan sampai pelaporan hasil praktikum, e) siswa antusias saat guru mengajak praktikum pada pertemuan kedua, f) siswa mulai senang mempelajari biologi melalui praktikum alga biru, g) siswa belajar berbagi tugas dengan kelompoknya pada saat praktikum, h) pada saat presentasi siswa satu dengan lainnya saling memberi penguatan untuk bisa tampil di depan kelas, i) pada saat tanya jawab siswa sudah mulai berani tunjuk tangan untuk menjawab pertanyaan.

Hasil refleksi siklus II dinyatakan bahwa: a) guru memberi pengarahan mengenai format laporan praktikum, b) 
masih ada $14,28 \%$ siswa belum termotivasi untuk tanya jawab dalam diskusi, c) siswa nampak saling tunjuk antar teman, tidak ada yang berinisiatif tunjuk tangan, d) praktikum yang dilakukan siswa sudah mulai tertib, e) fasilitas LCD dan laptop sudah digunakan saat kegiatan diskusi, f) presentasi secara berpasangan dapat memotivasi siswa untuk tampil di depan kelas.

Keterlibatan siswa secara aktif dapat diamati dalam 4 indikator motivasi yaitu attention, relevance, confident, dan satisfaction atau yang lebih dikenal sebagai model ARCS. Motivasi model ARCS adalah suatu model untuk menciptakan motivasi pada materi pembelajaran (Setjo, 2004). Peningkatan motivasi belajar siswa dapat dilihat dari peningkatan indikator motivasi yang diamati selama siklus I dan siklus II. Peningkatan terjadi pada indikator attention, relevance, confident, dan satisfaction dari siklus I ke siklus II. Berdasarkan Gambar 1 terjadi peningkatan pada pada keempat indikator motivasi. Indikator attention mengalami peningkatan $15 \%$. Peningkatan indikator attention terjadi karena rasa keingintahuan siswa terhadap objek yang dipelajari. Rasa ingin tahu siswa muncul karena siswa selalu diajak untuk mengamati langsung kejadian yang ada di sekitarnya. Siklus I siswa diajak mengamati monera berupa alga biru yang hidup pada akar tanaman paku air pada kolam di sekolah.

Siklus II siswa diajak mengamati protista perairan rentan terhadap pencemaran. Attetion muncul didorong rasa ingin tahu, yang dirangsang melalui elemenelemen baru, aneh, lain dengan yang sudah ada, kontradiktif atau kompleks. Perasaannya senang akan membantu siswa berkonsentrasi dalam belajarnya dan sebaliknya siswa dalam kondisi tidak senang maka kurang berminat dalam belajarnya. Siswa tersebut akan mengalami kesulitan untuk berkonsentrasi terhadap kegiatan pembelajaran yang sedang berlangsung. Hal ini sesuai dengan pernyataan Susanto (2002) yang menyebutkan bahwa motivasi belajar siswa tinggi jika mereka memusatkan perhatian lebih besar kepada kegiatan belajar daripada kegiatan yang bukan belajar.

Peningkatan juga terjadi pada indikator relevance, indikator relevance meningkat karena selama siklus II siswa dapat memahami apa yang dipelajari selama kegiatan pembelajaran. Siswa difasilitasi untuk mencari informasi dan berdiskusi agar memahami materi pembelajaran protista dan peranannya. Siswa dapat menjawab pertanyaan berdasarkan pengalamannya di lingkungan atau sebaliknya, siswa dapat menerapkan pengetahuan yang diperoleh selama kegiatan pembelajaran pada kehidupan sehari-hari. Adanya relevance yang tinggi dapat meningkatkan motivasi sesuai dengan pernyataan Qadriyah (2002) bahwa motivasi siswa akan terpelihara apabila mereka mengganggap yang dipelajari memenuhi kebutuhan pribadi atau bermanfaat dan sesuai dengan nilai yang dipegang.

Berdasarkan refleksi siklus I indikator confident mendapat pencapaian terendah dibandingkan dengan indikator lain, yaitu mencapai $40 \%$. Hasil refleksi siklus II guru berusaha untuk meningkatkan kepercayaan diri siswa dengan memberikan motivasi dan apresiasi terhadap siswa yang aktif mengemukakan pendapat maupun bertanya. Kegiatan diskusi diawali dengan kelompok kecil yang terdiri dari dua siswa dan selanjutnya berkembang menjadi kelompok besar. Kegiatan diskusi dilakukan untuk meningkatkan kepercayaan diri siswa dan meningkatkan pemahaman siswa terhadap materi. Adanya pertanyaan atau masalah merupakan rangsangan dari guru maupun siswa lain dapat menjadi tuntunan siswa dalam mengontruksi pemecahan masalah yang dapat berupa pendapat atau jawaban siswa sehingga siswa lebih confident. Menurut Dimyati dan Mudjiono (1994) motivasi intrinsik mendorong terus dan memberikan energi pada tingkah laku. Motivasi intrinsik mengarah pada timbulnya motivasi berprestasi, sehingga diperlukan adanya confident atau rasa percaya diri. Berdasarkan hasil penelitian confident yang berasal dari dalam diri siswa bertujuan untuk 
menunjukkan bahwa siswa tersebut berprestasi masih sangat kurang.

Indikator satisfaction atau rasa puas mencakup kepuasan atas jawaban yang diberikan teman atau guru dan kehadiran di kelas. Kehadiran di kelas termasuk indikator satisfaction karena kehadiran siswa di kelas menunjukkan bahwa siswa puas terhadap pembelajaran yang berlangsung. Siklus II terjadi peningkatan satisfaction membuktikan bahwa siswa merasa puas terhadap jawaban atau pemecahan solusi yang dijelaskan oleh teman atau guru. Siswa puas terhadap pembelajaran yang ditunjukkan siswa hadir di kelas selama kegiatan pembelajaran berlangsung. Satisfaction siswa akan meningkat apabila memperoleh penghargaan atas keberhasilan yang diperoleh. Penghargaan dapat berupa reward, reinforcement, atau pujian dari guru. Selama siklus II guru lebih sering memberikan pujian terhadap siswa yang bersedia menyampaikan pendapatnya atau menjawab pertanyaan. Adanya pujian dari guru menyebabkan siswa merasa telah berhasil dalam mencapai tujuan yang diharapkan. Keberhasilan dalam mencapai tujuan akan memberikan kepuasan tersendiri bagi siswa dan siswa akan berupaya untuk mencapai tujuan lainnya dengan berhasil pula. Siswa akan meningkat satisfaction-nya apabila hasil kerja mereka dihargai oleh orang lain.

Motivasi belajar siklus II mengalami peningkatan jika dibandingkan dengan siklus I. Motivasi belajar siswa siklus I sebesar 68,333, Motivasi belajar siklus II sebesar $93,056 \%$. Peningkatan terjadi karena beberapa faktor, yaitu a) selama pembelajaran siswa melakukan proses diskusi bersama teman-temannya dengan model TPS, b) model TPS siswa diberi kesempatan membangun pemahamannya sendiri dengan diberi waktu tunggu dan diberi kesempatan berpikir bersama teman. Menurut Dasna dan Sutrisno (2006) siswa harus menemukan dan membangun sendiri struktur kognitif/pengetahuannya melalui interaksi dan transaksi, sehingga siswa akan membangun sendiri konsep pengetahuannya secara tidak langsung dan berbagi informasi.

Pembelajaran praktikum protista, guru memfasilitasi siswa untuk mengamati protista yang ada di perairan sekitar tempat tinggal siswa. Guru mengajak siswa memikirkan apa yang terjadi dengan protista perairan. Menurut Edgar Dale (dalam Hasibuan, 2000) menyatakan bahwa belajar paling baik adalah belajar melalui pengalaman langsung, dengan demikian siswa tidak hanya sekedar mengamati secara langsung tetapi ia harus menghayati, terlibat langsung dalam pembuatan dan bertanggung jawab terhadap hasilnya. Pembelajaran kooperatif model TPS membantu siswa untuk berinteraksi dengan teman-temannya maupun lingkungan. Siswa lebih percaya diri dan mudah untuk membangun konsep pengetahuannya dengan interaksi dan pengamatan langsung. Pembelajaran model TPS guru memfasilitasi siswa untuk mendiskusikan hal-hal yang ditemui pada saat praktikum. Menurut Slavin (1996) dalam Sanjaya (2006) menyatakan bahwa pembelajaran kooperatif terdapat perspektif sosial, artinya melalui pembelajaran kooperatif setiap siswa akan saling membantu dalam belajar karena mereka menginginkan semua anggota kelompok memperoleh keberhasilan.

Ibrahim (2000) menyatakan bahwa pembelajaran kooperatif lebih unggul dalam meningkatkan hasil belajar dibandingkan dengan pengalaman-pengalaman belajar individual atau kompetitif. Pembelajaran kooperatif model TPS di SMAN 1 Barat kelas X-7 dapat meningkatkan motivasi dan hasil belajar siswa. Lebih lanjut juga diungkapkan oleh Ludgren (1994) dalam Dasna dan Sutrisno (2006) menyatakan keuntungan pembelajaran kooperatif antara lain meningkatkan prestasi akademik, mengurangi konflik antar individu dan meningkatkan motivasi belajar. Pembelajaran TPS dapat mengembangkan kecakapan hidup sosial siswa. Siswa dapat mengalami (a) saling ketergantungan positif karena siswa belajar dari satu sama lain, (b) menjunjung akuntabilitas individu karena 
mau tidak mau mereka harus saling berbagi ide, dan wakil kelompok harus berbagi ide pasangannya dan pasangan lain atau keseluruh kelas, (c) mempunyai kesempatan yang sama untuk berpartisipasi karena seyogyanya tidak boleh ada siswa yang mencoba mendominasi dan (d) interaksi antar siswa cukup tinggi karena akan terlibat secara aktif dalam sengaja berbicara atau mendengarkan.

\section{SIMPULAN}

Penerapan model TPS dapat meningkatkan belajar Biologi siswa kelas X7 SMAN 1 Barat. Pembelajaran kooperatif Model TPS dapat mengatasi masalah keraguan untuk menyatakan pendapat dan meningkatkan rasa percaya diri siswa.

\section{DAFTAR PUSTAKA}

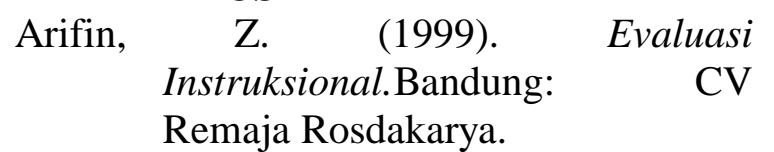

Dasna dan Sutrisno. (2006). Model-model Pembelajaran Konstruktivistik dalam Pengajaran Sains/Kimia. Malang: Universitas Negeri Malang

Dimyati dan Mudjiono. (2002). Belajar dan Pembelajaran. Jakarta: Rineka Cipta.

Hasibuan dan Sultoni. (2000). Kemampuan Dasar Mengajar. Malang: FIP Universitas Negeri Malang

Ibrahim. (2000). Pembelajaran Kooperatif. Surabaya: Universitas Negeri Surabaya Keller, J.M. (1987). IMMS: Instructional materials motivation survey. Florida: Florida State University

Oktrianawati, I. (2005). Penerapan Pola PBMP dengan metode Numbered Heads Together untuk Meningkatkan Keterampilan Berpikir Tingkat Tinggi dan Hasil Belajar Siswa Biologi Kelas II SMP Shalahuddin
Malang. Skripsi tidak diterbitkan. Malang: FMIPA UM.

Prayitno, E. (1989). Motivasi dalam Belajar. Jakarta: Proyek Pengembangan Lembaga Pendidikan Tenaga Kependidikan.

Qadriyah. (2002). Upaya Peningkatan Motivasi dan Hasil Belajar Biologi melalui Penerapan Pembelajaran Kooperatif (Tipe STAD) pada SMU Wahid Hasyim Malang. Tesis tidak diterbitkan. Malang: Universitas Negeri Malang.

Sanjaya, W. (2006). Pembelajaran Dalam Implementasi Kurikulum Berbasis Kompetensi. Jakarta: Kencana Prenada Media Group

Sardiman. (2003). Interaksi dan Motivasi Belajar Mengajar. Jakarta: Rajawali Press.

Setjo, S. (2004). Motivasi dan Pengajaran Kontekstual. Makalah. Disampaikan pada Workshop Piloting IMSTEPJICA tanggal 23-24 Juli 2004 di FMIPA Universitas Negeri Malang.

Slavin, R.E. (1995). Cooperatif Learning : Theory Research, and Practice. Second Edition.Boston: Allyn and Bacon Publisher

Susanto, P. (2002). Strategi Pembelajaran Biologi di Sekolah Menengah. Malang: Universitas Negeri Malang.

Susilo, H.; Corebima, A.D., Ibrahim, M. (2006). Pemberdayaan Kemampuan Berpikir Siswa dan Mahasiswa Melalui Pembelajaran Kontekstual dalam Mata Pelajaran atau Mata Kuliah IPA/Biologi. Laporan Penelitian tidak diterbitkan. Malang: Lemlit UM.

Tim Penyusun Kamus Pusat Pembinaan dan Pengembangan Bahasa. (1989). Kamus Besar Bahasa Indonesia. Cetakan ke 2. Jakarta: Balai Pustaka. 